\title{
ARID ZONE RESEARCH
}

$\mathrm{T}$ HE Advisory Committee on Arid Zone Research, set up by Unesco, recommended at its first meeting, held in April 1951, that special attention should be given to the collection of information and the discussion of problems concerning arid zone hydrology and particularly water supply. 'Thus on the Committee's advice, Unesco obtained and is printing a series of reports on hydrology and its problems in the arid areas of the world written by a number of authors, together with climatological maps of such areas.

Unesco in 1952 also organized, jointly with the Government of Turkey, a symposium on "Hydrology of the Arid Zone" which was held in Ankara during April 25-29. This conference was opened by the President of the Turkish Republic. Papers were given by representatives of about a dozen nations and dealt with : (1) the staties and dynamies of underground water; (2) its physical and chemical properties; (3) the hydrological balance and the effects of water utilization; (4) methods of prospecting for water; (5) the relation of hydrology to other sciences. Each of these subjects was introduced by a general review paper, after which papers were given on particular aspects of it. Many of the papers aroused considerable interest and provoked active discussion, and it was generally thought that the conference had proved very useful. Its proceedings will be published. Visitors taking part in the symposium received very kind hospitality from the Turkish authorities during and after the meeting. This included an excursion to part of the arid area of Central Turkey.

The Advisory Committee on Arid Zone Research also held its third meeting in Ankara in April. In its recommendations it followed its policy of giving priority to the collection, dissemination and discussion of information. Thus it recommended the preparation and printing of reviews of research on : (1) arid zone plant ecology ; (2) sources of energy available in arid regions. Symposia on these two subjects were proposed for 1953 and 1954 respectively. On the Committee's recommendation, Unesco gave financial help to the Government of Israel in publishing the proceedings of its Symposium on Desert Research that was held in Jerusalem during May 7-14 (see below) and to the Institute of Biology (U.K.) to help towards the travel expenses of participants in its symposium on the "Productivity and Biology of Hot and Cold Deserts" that is to be held on September 25-27 next in London.

Unesco has asked its member States to appoint persons from whom advice may be obtained in a number of fields related to arid zone research. Such panels of experts have now been appointed by fifteen States and have already proved useful. The Committee recommended that this scheme be extended.

It also considered the preparation of a handbook that should give advice on the collection of basic data needed in planning the development of arid areas.

A scheme is now in operation in which certain research institutions, carrying out research in arid areas or concerned with their development, may be designated as suitable for the exchange of personnel and information and for the reception of visiting scientists. After considering their qualifications, the Committee recommended that the following institutions be added to those already designated.
Particulars about them can be obtained from Unesco : (a) Fen Fakultesi Botanik Enstitusu (Institute of Botany, Faculty of Science), University, Ankara, Turkey; (b) Department of Botany and its Geobotanical Research Laboratory of the Negev, Hebrew University, Jerusalem, Israel ; (c) Institut Français d'Afrique Noire, Dakar, French West Africa; (d) Jaswant College, Jodhpur, India ; (e) Tohum Islah ve Deneme Istasyonu (Seed Improvement Station), Eskischir, Turkey.

The Committee considered the question of giving travel grants to men of science desiring to carry out research or make field studies abroad. It recommended that the Director-General might give such assistance in a limited number of cases provided : " $(a)$ that the proposed research or field study comes within the scope of the Arid Zone Programme; (b) that the work is of importance to severat Unesco Member States having arid and semi-arid areas; (c) that the results of the work will be freely available to the public ; $(d)$ that the request for transportation assistance by the individual is supported by the Unesco National Commission in his country; $(e)$ that the individual has obtained approval for the research or field study from the appropriate authority at the institution or in the area in which the work is to be done".

On the research side the Committee recommended a small grant to assist in the study of the vegetation on certain nitrate- and sulphate-rich soils in South Algeria.

H. G. THORNTON

AN international symposium on "Desert Research", organized by the Research Council of Israel in cooperation with Unesco, was held in Israel during May 7-14. The growing interest in research devoted to various aspects of arid zones and their reclamation has been further stimulated by Unesco's activities, especially by the establishment of the Arid Zone Research Committee, and by the Unesco symposium on "Hydrology of the Arid Zone" (see above). The symposium in Israel was the first of its kind to be organized by a member-state of Unesco, and the first the programme of which did not restrict itself to one special subject of arid zone research but included several topics, and gave the opportunity for scientists in those fields of research to get an integrated picture of various aspects of desert research.

About fifty-five men of science from eighteen countries attended the symposium. At the opening ceremony in Jerusalem guests were welcomed by the Prime Minister, Mr. D. Ben-Gurion. Dr. Shen-Yi, chief of the bureau of Flood Control of the U.N. Economic Commission for Asia and the Far East, brought the greetings of the Secretary-Ceneral of the United Nations, and Dr. F. J. Malina, of the Natural Science Department of Unesco, spoke on behalf of the Director-General of his organization. A short outline of the significance of the symposium was given by Dr. W. C. Lowdermilk, F.A.O. Adviser to the Government of Israel, who presided over the symposium.

Three days were devoted to scientific sessions in Jerusalem, the next three days to scientific excursions in the Negev, the Coastal Plain, and Galilee, and a final day to further scientific sessions in the Institute of Technology, Haifa. 
Among the general papers were those by Leighly (United States) on "Dry Climates : their Nature and Distribution"; Kellogg (United States) on "Potentialities and Problems of Arid Soils" ; Monod (France) on "Biology and Arid Regions" ; and Bagnold (Great Britain) on "The Surface Movement of Blown Sand in Relation to Meteorology". According to Prof. F. B. Leighly, the extent of areas with a deficient water balance can be correlated with the wavepattern of the mean isobars at a height of $3 \mathrm{~km}$. above sea-level. Dr. D. Amiran (Israel) pointed out that the boundaries of semi-arid areas in Israel are continually shifting except where they are nearly fixed by the topography of the area, as in the Jordan rift.

There was complete agreement with Dr. E. C. Kellogg in his emphasis on economic and social factors in the utilization of arid and semi-arid soils, and interest in his view that in this area undergrazing as well as over-grazing constituted a danger with regard to soil erosion.

After a survey of the present position of biological research for arid zones by Prof. Th. Monod, Dr. R. A. Bagnold spoke on the mechanism of soil and sand transport by wind and explained his theory on the relation of the formation of sand ridges to the thermal structure of the atmosphere. Prof. C. W. Thornthwaite (United States) referred to some further data in support of Dr. Bagnold's figures.

Papers on climatology and meteorology in arid and semi-arid regions were read by Prof. P. Meigs (United States), Prof. C. W. Thornthwaite (United States) and Mr. S. Duvdevani (Israel). Prof. Meigs dealt with the preparation of homo-climatic maps, and showed in particular a map of Israel and Jordan. $\mathrm{He}$ discussed the parameters to be used in the preparation of these maps. Prof. Thornthwaite dealt with problems of water planning, stressing the importance of assessing potential evapo-transpiration, the amount of which can under certain circumstances be found by using phenological indications as accurately as by special measurements. The discussion on this paper was concerned with the uniformity of the water-storage capacity of soils, evapo-transpiration from various growths, and the use of atmospheric measurements to ascertain irrigation needs; for a first planning the nature of the crop is not considered of critical importance in assessing these needs. Mr. Duvdevani had measured the dew deposit on a prepared surface at various heights above the ground. The deposit at stations $1 \mathrm{~m}$. or less above the ground depends on the topography, the soil and the season, and particularly on the water content of the uppermost layer of the soil ; above a wet soil the deposit decreases upwards, above a dry soil it first increases and then decreases. 'The physical meaning of these measurements was raised in the discussion without conclusion.

Six papers were read in the Section on Soils. Prof. E. S. Hills's (Melbourne) lecture dealt with the relationship of physiography and climate, and with the influence of former physical conditions (as found from 'fossil' lateritic soils and sand ridges now bearing vegetation) and geomorphic features and patterns of natural drainage. The dramatically sudden and devastating effects of locally produced floods in desert areas was the main subject of Dr. W. C. Lowdermilk's lecture. Prof. A. Reifenberg (Israel), in a historic survey, showed the relationship of the encroachment of the desert to stable social conditions of government. Prof. G. Aubert (France) stressed how soils science had applications in the planning of irrigation, and Prof. S. Ravkovitz (Israel) dealt with the wind transport of soil material ; according to him the salts in the loess soils in the Southern Desert of Israel were probably wind-borne from the Dead Sea. Dr. G. Leone's (Italy) lecture on the stabilization and re-vegetation of coastal dunes of Tripolitania introduced a discussion which stressed a similar state of affairs in this respect in the whole Mediterranean area.

The lectures in the Section on Biology were manysided, embracing human physiology, general ecology, zoology and phytology, all with emphasis on desert environment. Dr. W. S. Ladell (Nigeria) gave a review on the physiology of life in high ambient temperatures which included the result of his research during the past ten years. He stated that Europeans temporarily resident in a tropical climate learn to tolerate severe heat with less discomfort than the local inhabitants. He refuted the theory that warm climates are detrimental to health and to productive work. $\mathrm{He}$ held the view that white settlers in hot regions had succumbed, when they had succumbed, to disease rather than to climatic factors. Ladell also discussed the physiological changes in the course of acclimatization to heat, the role of sweat and chlorine loss and of the central regulation mechanism involved. He stressed the point that in order to become acclimatized one has to expose oneself and not carefully to avoid exposure. Prof. F. S. Bodenheimer (Israel) spoke on the physiology of animals in arid zones with special reference to the frequent occurrence of dark and black colours.

Prof. F. W. Went (United States) spoke about the different germination mechanisms of desert plants which inhibit their germination at the wrong temperatures or after insufficient rains. $\mathrm{He}$ stressed the role of water in the germination of desert annuals. When the soil was kept wet all the time no germination occurred for many species. The reason for this lies in the presence of germination inhibitors inside the seeds, which are not leached out by small amounts of precipitations. With too much rain not only the inhibitors but also a growth-promoting substance is leached out. The inhibitors are formed continuously as soon as the seeds are wet. Dr. H. G. Thornton (Great Britain) dealt with his new approach to microbiological research work on desert soils, and Prof. Ch. Killian (France) gave a description of the vegetation of the Chott Hodna (Algiers) and analysed its edaphic conditions. The results are indicator values of the various plant communities, particularly with regard to chemical properties. Dr. B. T. Dickson (Australia) and Dr. P. C. Duisberg (United States) dealt in particular with plants in arid and semi-arid zones, Dickson with the Australian experience of transplanting plants into Australia, and Duisberg with the commercial utilization of desert plants from North America. Afforestation in arid areas was the subject of Sir Harold Glover's (Great Britain) lecture, which contained advice for planting, seeding and felling in such a way as to minimize the encroachment of the desert. Prof. M. Even-Ari (Israel) gave a short account of the water balance of desert plants, especially their adaptation to the dry season by decreasing their transpiring surface. Dew formation and active condensation of water vapour out of the atmosphere possibly constitute additional water sources for these plants. In the discussion, Prof. Went pointed out that the real suction forces of plants are apparently much stronger than those 
obtained by cryoscopic measurements of osmotic values.

Prof. A. Bonne (Israel) and Dr. M. Ezekiel (F.A.O.) presented the point of view of the economist and explained the importance both of economic planning and of general economic and statistical surveys of food requirements. Prof. M. R. Huberty (F.A.O.) explained the structure and purpose of the Food and Agriculture Organization with special reference to its activities in the field of ground-water studies.

Introductory to the excursions, Mr. P. L. O. Guy (Israel) gave an account of the remnants of the soil and water conservation service which existed in the Kurnub upper-catchment area during the Byzantine period and suggested that the site should be rebuilt as an experimental reserve; Mr. A. de Leeuw (Israel) outlined the overall irrigation scheme for Israel with special emphasis on the problem of water storage.

In the session held in Haifa, Mr. E. W. Golding (Great Britain) told of recent British experience on the utilization of wind-power for the generation of electricity by windmills of modern type, and gave a general discussion on the economic exploitation of wind energy with particular reference to this region. The remaining papers of the last day dealt with problems of ground water and water in soils. Dr. P. Danel (France) dealt with the physics and the measurements of the flow of ground water and with the application of the methods of measurement which he and his co-workers in Grenoble had developed. Dr. L. A. Richards's (United States) papers also dealt largely with the technique of measurements, in this case with the physical properties of soils, especially as regards their power to retain water. The relevance of such measurements to irrigation methods was discussed, as well as the foundations of the new subject of soil physics. The paper of Dr. A. N. Khosla (India) was read by his colleague, Dr. R. D. Dhir, and dealt with the relation of surface water and ground water in arid zones. He gave a simple formula which he has applied successfully to several catchment areas in India to determine the yearly run-off from catchment areas. The formula is based on monthly average temperatures only. In the discussion it was pointed out that Dr. Khosla's method may be correlated to Thornthwaite's method of evapo-transpiration. Prof. L. Pjcard (Israel) reviewed the history of ground-water investigations, and Dr. M. G. Drouhin (Algiers) spoke on hydrological studies in desert regions.

In the closing session Sir Ben Lockspeiser (Great Britain) summed up his impressions of the conference, followed by a discussion to which, among others, Kellogg and Monod made valuable contributions. It appears that the main lessons to be learned from this symposium are as follows: (1) Desert research requires many disciplines, and although men of science usually prefer to talk to specialists in their own discipline, a conference of this type bringing together the various experts dealing with arid zones is valuable and should be repeated every four or five years. (2) In all the branches men of science are still struggling to clarify their ideas; in some of them even commonly accepted definitions and terminology are still lacking. Nevertheless, (3) the biggest hindrance to progress at the present time is the lack of available data in branches where there is common agreement on which data should be assembled, and there are generally accepted techniques for assembling them. This is true particularly for soil and water studies and also for certain specialized meteorological data. The members of the conference unanimously accepted the following resolutions :

"This symposium wishes to draw the attention of the Director-General of Unesco to the following resolutions :

"1. That interested Governments be invited to strengthen existing research devoted to various problems of arid zones at existing national centres with a view to $(a)$ encouraging fundamental research, and $(b)$ the eventual creation of national bodies where the practical problems of each area can be brought to a focus and considered as a whole.

" 2 . That the effort devoted to field surveys, undertaken to obtain the basic data on the arid zones, should be extended and means provided for increased training facilities for technical personnel required for field studies and operations.

"3. The symposium attaches great importance to the exchange of scientists and the sharing of training facilities on an international basis.

" 4 . The symposium appreciates the practical interest and support of arid zone research and development of the United Nations, its Specialised Agencies and of international non-governmental scientific organizations, and warmly supports the recommendation of the Advisory Committee on Arid Zone Research that Unesco should initiate steps for the preparation of a handbook to guide collection of basic data".

The proceedings of the symposium will be published by the Research Council of Israel with financial support by Unesco.

S. GoLdstern

\section{THE SCIENCE OF DOMESTIC HEATING*}

$T$

HE subject of domestic heating is of particular interest at the present time in Great Britain when the quantity of coal for use in homes may well have to be reduced as a result of both the everincreasing demand for coal to satisfy the expanding power requirements of industry and the urgent economic need to export more coal.

Coal must continue to be the principal domestic fuel in Britain for many years to come, the supply of alternative fuels being totally inadequate for this purpose, so that there is every incentive to improve heating methods 'and appliances with the view of obtaining more heat and comfort from less coal. Furthermore, the greater scarcity of coal and its rising cost, together with an advance of scientific techniques and equipment, have given an added impetus to a more scientific approach to the problem during recent years.

The chimney fireplace was first introduced into England during Norman times and was the beginning of the familiar open fire of to-day. The early chimneys were large and troublesome; but their size was reduced only slowly, and it was not until Rumford suggested a narrowing of the throat of the fire, to reduce room draughts and to combat down-draught, that any marked improvement occurred. A further restriction of the throat, with consequent additional advantage, followed upon the introduction of cast iron as a

* Summary of a Friday Evening Discourse delivered to the Royal Institution on May 16 by Mr. J. S. Hales, of the British Coal Utilisation Research Assorlation. 